\title{
An inquiry into EFL teachers' beliefs concerning effective teaching, student learning and development
}

\author{
Gülten Koşar ${ }^{1}$ and Sevda Doğan Dolapçığlư ${ }^{2}$ \\ ${ }^{1}$ Hatay Mustafa Kemal University, Faculty of Education, Turkey (ORCID: 0000-0002-4687-4382) \\ ${ }^{2}$ Hatay Mustafa Kemal University, Faculty of Education, Turkey (ORCID: 0000-0002-2707-1744)
}

\begin{abstract}
How teaching could be conducted effectively and consequently student learning could be enhanced presumably vary from teacher to teacher, arising from a variety of such factors as the conditions in the workplace, teachers' year of teaching experience and their prior schooling experiences. In this regard, English-as-a-foreign-language (EFL) teachers' (EFLTs) beliefs about quality teaching leading to facilitated student learning are also highly likely to be divergent. This survey research aims to add to the growing literature on teacher beliefs via unveiling EFLTs' $(N=520)$ beliefs regarding effective teaching in general and effective EFL teaching in particular, student learning and development, and the probable changes that may occur in their beliefs according to the year of their teaching experience and the level of education they teach. The results revealed that the EFLTs held strong beliefs with respect to the effect of constructivist and humanistic concepts on effective teaching and student learning, and believed implementing communicative approach and conducting interactive activities induced effective EFL teaching and student learning. The findings also indicated that there existed statistically significant differences in EFLTs' beliefs concerning constructivist concepts and EFL teaching practices according to the year of their teaching experience.
\end{abstract}

Keywords: EFLTs; EFLT beliefs; Effective teaching; Level of education; Teaching experience

Article History: Submitted 5 May 2021; Revised 31 August 2021; Published online 13 September 2021

\section{Introduction}

Belief is defined by Borg (2001) as "... a proposition which may be consciously or unconsciously held, is evaluative in that it is accepted as true by the individual, and is therefore imbued with emotive commitment; further, it serves as a guide to thought and behaviour" (p. 187). In keeping with the definition of belief, Pajares (1992) describes teacher belief as "an individual's judgment of the truth or falsity of a proposition (p. 316), and Kagan (1992) states "teacher belief is a particularly provocative form of personal knowledge that is generally defined as pre- or in-service teachers' implicit assumptions about students, learning, classrooms, and the subject matter to be taught" (p. 65). Teacher beliefs, in the construction of which prior schooling experiences occupy a prominent

Address of Corresponding Author

Gülten Koşar, PhD, Department of English Language Teaching, Hatay Mustafa Kemal University, Tayfur Sökmen Campus, 31060, Hatay, Turkey.

$\triangle$ gencoglugulten@gmail.com

How to cite: Koşar, G., \& Doğan-Dolapçığlu, S. (2021). An inquiry into EFL teachers' beliefs concerning effective teaching, student learning and development. Journal of Pedagogical Research, 5(3), 221-234. https://doi.org/10.33902/JPR.2021371747 
role (Bernstein et al., 2018; Moodie, 2016), are teacher-dependent; for instance, according to Baggett (2018), teacher beliefs about students are bound to individual teachers.

Teacher beliefs are one of the constituents of teacher cognition, delineated by Borg (2003) as "unobservable cognitive dimension of teaching -what teachers know, believe, and think" (p. 81), and exert a substantial impact on language teachers' instructional practices and the chances they offer to students (Gkonou et al., 2018; Pettit, 2011; Phipps \& Borg, 2009; Portolés \& Martí, 2020; Rijt et al., 2020; Swierzbin \& Reimer, 2019; Tam, 2012; Vries et al., 2014). In the same vein, Richards and Lockhart (2007) attest "beliefs and values serve as the background to much of the teachers' decision making and action" (p. 30). However, there could be a contradiction between teachers' beliefs about the way effective teaching could be realized and how they teach in the classroom (Devine et al., 2013; Tadesse, 2020).

Now that language teachers' beliefs about teaching and learning influence their teaching practices, they could also affect the degree of student language learning. Seeing the importance attached by teachers, parents, school administration and students to success in language learning, the importance to be placed on EFLT beliefs becomes evident. It is of high significance to conduct studies with practicing teachers to learn about why they teach in the way they do as they are the key figures to gain insights into their pedagogical practices (Borg, 1998). In addition, teachers can raise their awareness of how their beliefs determine what they do in the classroom (Farrell \& Ives, 2015) when digging out them. Literature review unveils that practicing EFLTs' beliefs as to effective teaching in general and EFL teaching in particular and student learning have not been investigated extensively. Moreover, there is a scarcity of research on investigating the relationship between teachers' year of teaching experience, the level of education they teach and their beliefs about effective teaching, student learning and development, and that between their beliefs about effective EFL teaching methods and techniques and the length of their professional experience and the level of education they teach. These gaps uncover the significant contribution to be made by the present study to the extant literature on teacher beliefs.

\subsection{Literature Review}

\subsubsection{Language teacher beliefs}

Language teachers' previous language learning experiences wield an enormous influence on their beliefs about effective teaching. For example, the EFLT participants in Nguyen's (2017) study stated that they believed their grammar-based learning experiences were an influential factor in their own pedagogical decisions. Teacher beliefs are postulated to be implicit and explicit (Fives \& Buehl, 2012) and if or not explicit beliefs correlated with implicit ones was investigated in the research by Harrison and Lakin (2018), reporting that teachers' implicit beliefs about English did not conform to those that were explicit.

Researches on teacher beliefs and practices reveal that there is both congruence and incongruence between teachers' stated beliefs and classroom practices (Feryok, 2008; Pham \& Hamid, 2013). Nonetheless, a fundamental number of extant researches indicate disparities between them (e.g., Graham et al., 2014; Muñoz \& Ramirez, 2015) in that how teachers teach may not reflect what they believe about how effective language teaching can be conducted, which can result from contextual variances. That is to say, the context in which teachers work impacts on teachers' classroom decisions and engenders differences between their beliefs and practices (Sanchez \& Borg, 2014; Watson, 2015). To illustrate, there was inconsistency between the beliefs of participating primary and secondary EFLTs in the research by Bai and Yuan (2019) regarding teaching pronunciation and their pronunciation teaching practices. Even though the participants emphasized the significance of pronunciation teaching, they could not teach it due to either institutional expectations about preparing students for examinations or not viewing themselves as efficacious at teaching it. Farrell and Bennis (2013) scrutinized the relationship between one novice and one-experienced teacher' beliefs about grammar teaching and their grammar teaching practices, and the results demonstrated disparities between what they believed about how 
grammar should be taught and how they taught it. Likewise, there was no exact correspondence between EFLTs' beliefs about language teaching and their classroom practices in Li's (2013) study. Highlighting the necessity of considering the role of teacher emotions in teacher cognition, Cheung and Leung (2020) also indicated the probability that teachers' classroom practices might or might not be in compliance with their beliefs.

Differences between core and peripheral beliefs are accentuated by Dale et al. (2018) as the source of mismatch between teachers' beliefs and their practices. Teachers' core beliefs were depicted to be more influential in their classroom practices (Zheng, 2013). Hawanti (2014) underscored in his paper on exploring primary teachers' beliefs about English curriculum and the way they taught English that they relied on their knowledge and beliefs about English language teaching in the absence of curriculum. The research by Deng and Carless (2010) demonstrated that apart from one EFLT, other three EFLTs, though they were conscious of the positive influence of implementing communicative approach on promoting children's foreign language learning, stated that traditional teaching methods maintained their place in their instructional practices with an eye to preparing them for exams. In contrast to the studies yielding the non-correspondence between what teachers state as their beliefs regarding teaching and learning and how they teach, there exit researches indicating the congruence between them (e.g., Li \& Walsh, 2011). It was exhibited in the research by Karimi et al. (2016) that EFLTs with high level of self-efficacy could adhere to their beliefs in their classroom practices regardless of the contextual constraints as against the ones with low level of self-efficacy. Besides the incompatibility between what teachers believe about how effective teaching should be carried out and their actual teaching practices, there could be inconsistency between their beliefs and their thoughts about effective teaching (Sato \& Oyanedel, 2019) for what teachers say may not be what they think (Sun et al., 2020).

The beliefs held by teachers and students about language learning showed both similarities and differences in the study undertaken by Davis (2003). To exemplify, in comparison to the teacher participants, the student participants more strongly believed that the earlier a second language is introduced in schools, the greater the likelihood of success in learning. The differences between native and non-native EFLTs' beliefs and practices were demonstrated in Gareca and Gui's (2019) study which yielded, as opposed to the commonly-held conception, Chinese EFLTs valued communicative language teaching yet also favoured the use of grammar-translation and audiolingual methods as against those of American EFLTs. Likewise, the research by Kissau et al. (2014) reported in spite of the fact that there existed a correspondence between American and German foreign language teachers' beliefs concerning effective foreign language teaching, incongruence existed between two groups of teachers, attributed to the divergence in contextual factors. EFLTs' beliefs about the place of culture teaching in EFL teaching could differ greatly (Gu, 2010). For instance, Ghavamnia (2020) reported that EFLTs could not incorporate the teaching of culture into their instructional practices although they believed that it was important to teach culture as well as language, which they elucidated by putting forward the lack of enough time for teaching culture.

\subsubsection{EFLTs' beliefs concerning effective language teaching}

English language teachers' beliefs about teaching and learning have been the subject of plenty of research (Crusan et al., 2016; Hayes, 2009; Lee \& Bathmaker, 2007; Liviero, 2017; Karabenick \& Noda, 2004; Knudsen et al., 2021; Murphy \& Torff, 2019; Nguyen et al., 2016). The study by Oder and Eisenschmidt (2018) exploring EFLTs' conceptions of effective teaching yielded that they strongly agreed with the statement that "teachers should vary their teaching methods to achieve students' meaningful learning and understanding", furthermore, they strongly favoured the statement that "students need to be given opportunities to discuss new ideas and listen to their classmates' ideas in small groups". Pointing out the value of effective teacher beliefs on effective teaching, Rosenfeld and Rosenfeld (2008) suggested conducting a constructivist and collaborative professional development course for teachers to develop effective beliefs. The study participants in Young and Sachdev's (2011) acknowledged the place of culture teaching in the development of 
students' intercultural communicative competence but highlighted the need for the training in broadening their knowledge of culture teaching.

Practicing EFLTs' beliefs about effective language teaching and learning are prone to change as a result of trainings provided for them (e.g., Borg, 2011). For instance, Anderson (2020) reported the shifts in EFLTs' beliefs as regards how languages are taught and learnt best towards communicative and student-centred teaching; nonetheless. Similarly, Chaaban (2017) reported changes in primary EFLTs' beliefs concerning the teaching of EFL and their teaching practices by virtue of the teacher education course they were offered.

$>$ This research aims to find answers to the following research questions:

$>$ What are EFLTs' beliefs about effective teaching, student learning and development?

$>$ Do EFLTs' beliefs of effective teaching, student learning and development change significantly according to the year of their teaching experience and the level of education they teach?

$>$ What are EFLTs' beliefs as to effective EFL teaching methods and techniques?

$>$ Do EFLTs' beliefs as to effective EFL teaching methods and techniques change in accordance with the year of their teaching experience and the level of education they teach?

\section{Method}

\subsection{Research Design and Setting}

This research was designed as a survey research, which is employed so as to "identify beliefs and attitudes of individuals" (Creswell, 2012). Considering the purposes of the present study, unpacking EFLTs' beliefs about effective teaching in general and EFL teaching in part, student learning, and development, and whether or not their beliefs change according to the length of their professional experience and the level of education at which they teach, the rationale behind employing survey research design could be enlightened. The survey was e-mailed to EFLTs teaching at state primary, secondary and high schools. Information on English language curricula for primary, secondary and high schools will be presented to sort out how English is expected to be taught at three levels of education in the context of the current study. Since the English language curricula for primary and secondary schools are presented together as two components of primary education by the Ministry of National Education (2018), explanations as to them is given under the same sub-heading while a separate one is provided for the English language curriculum for high schools.

\subsubsection{English language curriculum for primary and secondary schools}

Following the adoption of 4+4+4 educational model in 2012 in the context of the study, teaching of English started to be conducted from grade 2 onward, which had been offered beginning from grade 4 prior to the change in the education system. The principles of the Common European Framework of Reference for Languages: Learning, Teaching, Assessment (CEFR) are closely followed in the new curriculum. It is highlighted in the curriculum adopting action-oriented approach that English should be taught using it is as a means of communication instead of teaching it as a subject packed with a myriad of words and structures to be transferred to students. Listening and speaking skills are prioritized in the curriculum, with no room for teaching reading and writing skills at grade 2 and with very/limited, in comparison to listening and speaking skills, emphasis on reading and writing skills at grades 3, 4, 5 and 6 . Further, reading and writing skills are secondary to listening and speaking skills at grades 7 and 8. English is offered two hours per week at grades 2,3, and 4, three hours per week at grades 5 and 6 , and 4 hours at grades 7 and 8 .

\subsubsection{English language curriculum for high schools}

Action-oriented approach is adopted in the curriculum for high schools (Ministry of National Education, 2018), the same as the curriculum for primary and secondary schools. The importance of providing English instruction in supportive and enjoyable learning environments in helping 
high schoolers become effective and fluent users of English is accentuated. Increasing learner autonomy is also underscored in the curriculum. English is offered four hours per week at grades 9-12.

\subsection{Participants}

The survey used the collect the data was e-mailed to 1,432 primary, secondary and high-school teachers and 564 responded to the e-mail, meaning 36\% of the EFLTS being e-mailed filled out the survey. Box-plot was run to find out if any outlier existed in the data. Forty-four outliers detected through box-plot were eliminated from the analysis. Purposive sampling was used in the selection of the participants inasmuch as EFLTs teaching at three levels of education were needed in this study to find answers to the research questions 2 and 4. Participation in the study was based on voluntariness. The participants were informed about the fact that they could withdraw from the study anytime they wished. Table 1 below displays demographic information about the participants.

Table 1

Demographic Information about the Participants

\begin{tabular}{llcc}
\hline Demographic & Keyword & $f$ & $\%$ \\
\hline Gender & Female & 386 & 74.2 \\
& Male & 134 & 25.8 \\
\hline Age group & $20-30$ & 176 & 33.8 \\
& $31-40$ & 274 & 52.7 \\
\hline Level of education & $41-50$ & 70 & 13.5 \\
& Primary school & 129 & 24.8 \\
& Secondary school & 277 & 53.3 \\
\hline Experience & High school & 114 & 21.9 \\
& $0-5$ & 133 & 25.6 \\
& $6-10$ & 198 & 38.1 \\
& $11-15$ & 114 & 21.9 \\
& $16-20$ & 75 & 14.4 \\
\hline
\end{tabular}

Table 1 shows that $74.2 \%$ of the participants were female and the remaining $25.8 \%$ of the participants were male. More than half of the participants were between the age group 31-40, while $33.8 \%$ of the participants were between the age range 20-30, and the rest were in the age group $13.5 \%$. More than half of the participants, $53.3 \%$, were teaching at a secondary school, $24.8 \%$ of the participants were teaching at a primary school and $21.9 \%$ at a high school. As demonstrated in Table 1, 38.1\% of the EFLTs had 6-10 years of teaching experience, $25.6 \%$ of the participants had 0-5 years of professional experience, $21.9 \%$ of the participants had been teaching for 11-15 years, and $14.4 \%$ had $16-20$ years of teaching experience when this study was conducted.

\subsection{Instrument}

The data collection tool is the 30-item and five-point Likert scale questionnaire developed by Oder (2014). The participants were to choose one option from among five options, ranging from strongly disagree to strongly agree for each item in the questionnaire. The questionnaire comprises two main categories, the first of which caters for unravelling EFLTs' beliefs concerning teaching, student learning and development (items: 1, 4, 5, 6, 10, 11, 14, 16, 17, 19, 22, 23, 24, 27, 29, 30; e.g., item 1: It is better when teachers, not students, decide which activities are to be used in the class.), which assessed their beliefs about traditional concepts (items 1, 4, 5, 10, 17, 24; e.g., item 5: A quiet classroom is needed for effective learning.), constructivist concepts (items 6, 11, 14, 16, 22, 23; e.g., item 11: The teacher's role is to facilitate students' enquiries.) and humanistic concepts of teaching and learning (items 19, 27, 29, 30; e.g., item 29: It is better for students to start learning English as early as possible). The second major category serves as an agent to learn about EFLTs' beliefs as to 
effective language teaching (items: $2,3,7,8,9,12,13,15,18,20,21,25,26$, 28; e.g., item 26: Knowledge about different cultures helps learning English.), assessing their beliefs of grammartranslation method (items 2, 8, 18, 25; e.g., item 18: The most important element in teaching English is vocabulary.), communicative approach (items 7, 12, 13, 15, 21, 26; e.g., item 7: It is important to be fluent in expressing one's thoughts in English.), and teaching practices (items 3, 9, 20, 28; e.g., item 9: Games, songs and other interactive activities are important to help students learn English.).

\subsection{Data Analysis}

Kolmogorov-Smirnov (K-S) test was run to reveal if the data were normal. K-S analysis indicated that there did not exist a normal distribution in the traditional concepts $(K-S=.09, p<.05)$, constructivist concepts $(K-S=.32, p<.05)$, humanistic concepts of teaching and learning $(K-S=.24, p<.05)$, grammar translation method $(\mathrm{K}-\mathrm{S}=.15, \mathrm{p}<.05)$, communicative approach $(K-S=.22, p<.05)$ and teaching practices $(K-S=.50, p<.05)$. Therefore, nonparametric test was used to analyse the data. Kruskal-Wallis test was performed to figure out whether EFLTs' year of teaching experience and level of education at which they teach lead to statistically significant differences in their beliefs about effective teaching and student learning, and beliefs about EFL teaching methods and techniques.

\section{Findings}

Findings will be presented under four distinct sub-headings in accord with the research questions.

\subsection{EFLTs' Beliefs about Effective Teaching, Student Learning and Development}

EFLTs' beliefs about traditional, constructivist and humanistic concepts were assessed with a view to learning about their beliefs concerning effective teaching, student learning and development. Table 2 illustrates the descriptive statistics results of EFLTs' beliefs about these concepts.

Table 2

Descriptive Statistics Results of EFLTs' Beliefs about Traditional, Constructivist and Humanistic Concepts

\begin{tabular}{lccc}
\hline Belief & $N$ & $\bar{X}$ & $S D$ \\
\hline Traditional concepts & 520 & 3.95 & .61 \\
Constructivist concepts & 520 & 4.75 & .32 \\
Humanistic concepts of teaching and learning & 520 & 4.52 & .50 \\
\hline
\end{tabular}

As seen in Table 2, the mean value of EFLTs' responses to the beliefs about traditional concepts is 3.95. The EFLTs substantially believed that multiple assessments should be implemented to evaluate student performance in the classroom (item 17). More than half of the participants (60\%) agreed with the statement that it is important to be accurate in expressing one's thoughts in English (item 10), and 59.4\% of the EFLTs believed that teaching students the rule of English language structure is important (item 4). More than half of the participants (59.2\%) agreed with the statement that a quiet classroom is needed for effective learning (item 5). Half of the participants agreed with the statement that it is important to acquire native-speaker pronunciation (item 24), and $45.6 \%$ of the EFLTs agreed with the statement that it is better when teachers, not students, decide which activities are to be used in the class (item 1 ).

Table 2 demonstrates that the mean value for EFLTs' responses to the beliefs regarding constructivist concepts is 4.75 . Almost all the participants $(98.5 \%)$ believed that making mistakes is normal in the learning process (item 22), and similarly, approximately all the EFLTs (96\%) agreed with the item that children acquire English easily when they are doing activities (item 16), the participants overwhelmingly $(89 \%)$ agreed with the statement that the teacher's role is to facilitate students' enquiries. $86 \%$ of the EFLTs believed that thinking and reasoning processes are more important than specific content items (item 6), and that students do not need to memorize the rules, but use them (item 23). $77.7 \%$ of the EFLTs agreed with the statement that students should have possibilities to deduce grammar rules themselves. 
Table 2 also shows that the mean value of EFLTs' responses to the beliefs as to humanistic concepts is 4.52 . Nearly all the participants (96.3\%) believed that students learn English with different learning styles in the classroom (item 19), and a substantial number of the participants $(93.1 \%)$ believed that it is best for students to start learning English as early as possible (item 29 ). $82.1 \%$ of the EFLTs agreed with the statement that students learn English more quickly than other languages because of external support (item 30), and virtually half of the participants (49.4\%) believed that every student can learn English well (item 27).

3.2. The Change in EFLTs' Beliefs about Effective Teaching, Student Learning and Development according to Level of Education They Teach and the Length of Their Professional Experience

Table 3 presents the results of Kruskal Wallis H-tests performed to investigate the statistically significant changes, if any, in EFLTs' beliefs about effective teaching, student learning and development according to the year of their teaching experience and the level of education they teach.

Table 3

Kruskal Wallis Test Results of EFLTs' Beliefs of Effective Teaching, Student Learning and Development

\begin{tabular}{|c|c|c|c|c|c|c|c|}
\hline Belief & Variable & Keyword & $N$ & Mean & $S D$ & $\chi^{2}$ & $p$ \\
\hline \multirow{7}{*}{$\begin{array}{l}\text { Traditional } \\
\text { concepts }\end{array}$} & \multirow{3}{*}{$\begin{array}{l}\text { Level of } \\
\text { education }\end{array}$} & Primary & 129 & 266.31 & \multirow[t]{3}{*}{2} & \multirow[t]{3}{*}{.68} & \multirow[t]{3}{*}{.71} \\
\hline & & Secondary & 277 & 255.42 & & & \\
\hline & & High & 114 & 266.28 & & & \\
\hline & \multirow{4}{*}{$\begin{array}{l}\text { Teaching } \\
\text { experience }\end{array}$} & $0-5$ & 133 & 254.90 & \multirow[t]{4}{*}{3} & \multirow[t]{4}{*}{1.43} & \multirow[t]{4}{*}{.70} \\
\hline & & $6-10$ & 198 & 264.34 & & & \\
\hline & & $11-15$ & 114 & 251.09 & & & \\
\hline & & $16-20$ & 75 & 274.61 & & & \\
\hline \multirow{7}{*}{$\begin{array}{l}\text { Constructivist } \\
\text { concepts }\end{array}$} & \multirow{3}{*}{$\begin{array}{l}\text { Level of } \\
\text { education }\end{array}$} & Primary & 129 & 269.89 & \multirow[t]{3}{*}{2} & \multirow[t]{3}{*}{.82} & \multirow[t]{3}{*}{.66} \\
\hline & & Secondary & 277 & 258.02 & & & \\
\hline & & High & 114 & 255.89 & & & \\
\hline & \multirow{4}{*}{$\begin{array}{l}\text { Teaching } \\
\text { experience }\end{array}$} & $0-5$ & 133 & 268.07 & \multirow[t]{4}{*}{3} & \multirow[t]{4}{*}{16.8} & \multirow[t]{4}{*}{$.00^{*}$} \\
\hline & & $6-10$ & 198 & 277.30 & & & \\
\hline & & $11-15$ & 114 & 260.56 & & & \\
\hline & & $16-20$ & 75 & 202.64 & & & \\
\hline \multirow{7}{*}{$\begin{array}{l}\text { Humanistic } \\
\text { Concepts }\end{array}$} & \multirow{3}{*}{$\begin{array}{l}\text { Level of } \\
\text { education }\end{array}$} & Primary & 129 & 272.88 & \multirow[t]{3}{*}{2} & \multirow[t]{3}{*}{4.17} & \multirow[t]{3}{*}{.12} \\
\hline & & Secondary & 277 & 248.50 & & & \\
\hline & & High & 114 & 275.65 & & & \\
\hline & \multirow{4}{*}{$\begin{array}{l}\text { Teaching } \\
\text { experience }\end{array}$} & $0-5$ & 133 & 267.26 & \multirow[t]{4}{*}{3} & \multirow[t]{4}{*}{7.05} & \multirow[t]{4}{*}{.07} \\
\hline & & $6-10$ & 198 & 245.63 & & & \\
\hline & & $11-15$ & 114 & 255.36 & & & \\
\hline & & $16-20$ & 75 & 295.59 & & & \\
\hline
\end{tabular}

As seen in Table 3, no statistically significant difference in EFLTs' beliefs regarding traditional concepts vis-à-vis the level of education they teach $\left[\chi^{2}=0.68 ; p>.05\right]$ and the year of their teaching experience $\left[\chi^{2}=1.43 ; p>.05\right]$ was observed. It is also depicted in Table 3 that a statistically significant did not exist in EFLTs' beliefs of constructivist concepts in relation to the level of education they teach $\left[\chi^{2}=0.82 ; p>.05\right]$ while a statistically significant difference exited according to the year of study $\left[\chi^{2}=16.8 ; p<.05\right]$. Kruskal Wallis $\mathrm{H}$ test was run to explore which group $(0-5 ; 6-10 ; 11-15 ; 16-20)$ caused the emergence of the difference. The analysis revealed that there were statistically significant differences between the beliefs held by EFLTs having 0-5 and 1620, 6-10 and 16-20, and 6-10 and 11-15 years of teaching experience, resulting from the fact that the mean values of the beliefs about constructivist concepts of the EFLTs with 0-5, 6-10 and 11-15 years of teaching experience were higher in comparison with the ones with 16-20 years of teaching 
experience. Table 3 also displays that EFLTs' beliefs with regard to humanistic concepts did not vary significantly according to the year of their teaching experience $\left[\chi^{2}=7.05 ; p>.05\right]$ and the level of education they teach $\left[\chi^{2}=4.17 ; p>05\right]$.

\subsection{EFLTs' Beliefs about Effective EFL Teaching Methods and Techniques}

Descriptive statistics was performed to learn about EFLTs' beliefs about grammar-translation method, communicative approach and teaching practices, providing insights into their beliefs concerning effective EFL teaching methods and techniques. Table 4 summarizes the results of the analysis.

Table 4

Descriptive Statistics Results of EFLTs' Beliefs about Effective EFL Teaching Methods and Techniques

\begin{tabular}{lccc}
\hline Methods $\mathcal{E}$ Techniques & $N$ & $\bar{X}$ & $S D$ \\
\hline Grammar-translation method & 520 & 2.79 & .72 \\
Communicative approach & 520 & 4.64 & .37 \\
Teaching practices & 520 & 4.90 & .27 \\
\hline
\end{tabular}

Table 4 shows that the mean value of EFLTs' responses to the beliefs regarding grammar translation method is 2.79. More than half of the EFLTs (61.9\%) believed that the most important element in teaching English is vocabulary (item 18), and 52.9\% of the EFLTs agreed with item 8, stating that students should understand every word they read. More than half of the participants $(52.1 \%)$ believed that the most important element in teaching English is grammar (item 25). 46.9\% of the participants agreed with the statement that teachers should always correct students' incorrect language (item 2).

The mean value of EFLTs' stated beliefs in communicative approach is 4.64. An overwhelming number of the participants $(95.6 \%)$ believed that reading, listening, speaking and writing should be taught in an interactive manner (item 12), and 94.2\% of the EFLTs agreed with the conception that it is important to recycle new vocabulary as much as possible (item 15). 86\% of the EFLTs agreed with the statement that English pronunciation, grammar and vocabulary should be taught in an integrative manner rather than separately (item 22). $86 \%$ of the participants believed that knowledge about different cultures helps learning English (item 26) and that grammar mistakes in communication are not important, provided the message is conveyed (item 13). Finally, $66.9 \%$ of the participants agreed with item 7 claiming it is important to be fluent in expressing one's thoughts in English.

Table 4 also demonstrates that the mean value of EFLTs' responses to the beliefs about teaching practices is 4.90 . Approximately all the participants (97.9\%) believed that games, songs and other interactive activities are important to help students learn English (item 9), and 96.2\% of the EFLTs agreed with the statement that group and pair work provide opportunities and motivation for communication (item 3). $95.4 \%$ of the EFLTs agreed with the conception that it is important to use a variety of multimedia equipment in teaching English (item 28), and 93.3\% of the EFLTs believed that singing and role-playing are appropriate English teaching activities (item 20).

\subsection{The Change in EFLTs' Beliefs about Effective EFT Teaching Methods and Techniques according to the Level of Education They Teach and the Length of Their Professional Experience}

Kruskal Wallis H-test was performed to determine the EFLTs' beliefs of effective EFL teaching methods and techniques. Table 5 demonstrates the results. 
Table 5

Kruskal Wallis test Results of EFLTs' Beliefs in Effective EFL Teaching Methods and Techniques

\begin{tabular}{|c|c|c|c|c|c|c|c|}
\hline $\begin{array}{l}\text { Methods \& } \\
\text { techniques }\end{array}$ & Variable & Keyword & $N$ & Mean & $S D$ & $\chi^{2}$ & $p$ \\
\hline \multirow{7}{*}{$\begin{array}{l}\text { Grammar- } \\
\text { translation } \\
\text { method }\end{array}$} & \multirow{3}{*}{$\begin{array}{l}\text { Level of } \\
\text { education }\end{array}$} & Primary & 129 & 268.32 & \multirow[t]{3}{*}{2} & \multirow[t]{3}{*}{1.76} & \multirow[t]{3}{*}{.41} \\
\hline & & Secondary & 277 & 263.41 & & & \\
\hline & & High & 114 & 244.58 & & & \\
\hline & \multirow{4}{*}{$\begin{array}{l}\text { Teaching } \\
\text { experience }\end{array}$} & $0-5$ & 133 & 259.67 & \multirow[t]{4}{*}{3} & \multirow[t]{4}{*}{.91} & \multirow[t]{4}{*}{.82} \\
\hline & & $6-10$ & 198 & 263.69 & & & \\
\hline & & $11-15$ & 114 & 250.12 & & & \\
\hline & & $16-20$ & 75 & 269.32 & & & \\
\hline \multirow{7}{*}{$\begin{array}{l}\text { Communicative } \\
\text { approach }\end{array}$} & \multirow{3}{*}{$\begin{array}{l}\text { Level of } \\
\text { education }\end{array}$} & Primary & 129 & 263.40 & \multirow[t]{3}{*}{2} & \multirow[t]{3}{*}{0.51} & \multirow[t]{3}{*}{.78} \\
\hline & & Secondary & 277 & 256.45 & & & \\
\hline & & High & 114 & 267.06 & & & \\
\hline & \multirow{4}{*}{$\begin{array}{l}\text { Teaching } \\
\text { experience }\end{array}$} & $0-5$ & 133 & 288.84 & \multirow[t]{4}{*}{3} & \multirow[t]{4}{*}{7.63} & \multirow[t]{4}{*}{.05} \\
\hline & & $6-10$ & 198 & 254.46 & & & \\
\hline & & $11-15$ & 114 & 252.76 & & & \\
\hline & & $16-20$ & 75 & 237.95 & & & \\
\hline \multirow{7}{*}{$\begin{array}{l}\text { Teaching } \\
\text { practices }\end{array}$} & \multirow{3}{*}{$\begin{array}{l}\text { Level of } \\
\text { education }\end{array}$} & Primary & 129 & 264.72 & \multirow[t]{3}{*}{2} & \multirow[t]{3}{*}{4.62} & \multirow[t]{3}{*}{.10} \\
\hline & & Secondary & 277 & 265.17 & & & \\
\hline & & High & 114 & 244.37 & & & \\
\hline & \multirow{4}{*}{$\begin{array}{l}\text { Teaching } \\
\text { experience }\end{array}$} & $0-5$ & 133 & 273.63 & \multirow[t]{4}{*}{3} & \multirow[t]{4}{*}{11.64} & \multirow[t]{4}{*}{$.01^{*}$} \\
\hline & & $6-10$ & 198 & 260.30 & & & \\
\hline & & $11-15$ & 114 & 265.61 & & & \\
\hline & & $16-20$ & 75 & 230.00 & & & \\
\hline
\end{tabular}

Table 5 shows that there was no statistically significant difference in EFLTs' beliefs about grammar-translation method arising from the year of their teaching experience $\left[\chi^{2}=0.91\right.$; $p>.05]$ and the level of education they were teaching when the study was carried out $\left[\chi^{2}=1.76 ; p>.05\right]$. In addition, no statistically significant change resulting from the level of education the EFLTs were teaching $\left[\chi^{2}=0.51 ; p>.05\right]$, and the year of their professional experience $\left[\chi^{2}=7.63 ; p>.05\right]$ was observed in their beliefs about communicative approach. Participants' beliefs about teaching practices did not change significantly according to the level of education they taught $\left[\chi^{2}=4.62 ; p>.05\right]$ whilst there existed a statistically significant difference in their beliefs in accordance with the year of their professional experience $\left[\chi^{2}=11.64 ; p<.05\right]$. Kruskal Wallis H-test showed that statistically significant differences were between the groups $0-5$ and 16-20, 6-10 and 16-20, and 11-15 and 16-20. The mean values belonging to the responses of the EFLTs with 0-5, 6-10 and 11-15 years of professional experience to the beliefs regarding teaching practices were higher than those with 16-20 years of teaching experience.

\section{Discussion}

One of the purposes of this study is unearthing practicing EFLTs' beliefs with regard to effective teaching, student learning and development, and whether or not there existed a difference between participating EFLTs' beliefs according to the year of their teaching experience and the level of education they were teaching when this research was conducted. The findings demonstrated that the EFLTs agreed more with the beliefs in constructivist and humanistic approaches rather than the traditional ones. These results indicate that the study participants favour performing the role of a facilitator instead of behaving like a director in the teaching process; additionally, they think that EFL students should play an active role in English language learning. EFLTs' beliefs about constructivist concepts could be viewed to be promising in that students need take control of their learning, rather than waiting for the commands of the teacher 
and/or being filled by the information transferred by them, to be users of English. Pertaining to participants' beliefs regarding humanistic approach, the results showed they overwhelmingly believe that EFL teaching should be conducted bearing in mind that classes involve student with different learning styles, necessitating tailoring the way teaching is done in compliance with how students learn. This finding is in line with Oder and Eisenschmidt's (2018) study reporting the need for fine-tuning teaching methods for meaningful learning to take place. Most of the EFLTs believed in the benefit of beginning to learn English as early as possible. This finding is, in part, in line with the research by Davis (2003) because it revealed that student participants, rather than the teacher participants, believed more in the advantage of starting to learn a language at an early age. In addition, the findings as to participants' beliefs of traditional concepts should be considered carefully though the mean value pertaining to it is lower than the two others. Almost half of the participants believed that teachers, not students, should decide which activities to use in the classroom, and more than half of the EFLTs believed in the significance of accuracy as speaking English, and viewed teaching grammar as important. The teachers participating in Deng and Carless's (2010) study stated they implemented traditional teaching methods in lessons to prepare students for exams, but they thought communicative approach was better for teaching English.

The analysis carried out to explore statistically significant changes in EFLTs' beliefs about effective teaching, student learning and development according to the length of their teaching experience and the level of education they teach revealed that their beliefs regarding traditional and humanistic concepts did not change significantly while a statistically significant difference was observed in their beliefs concerning constructivist approach in accord with the year of their professional experience. The values indicated that the EFLTs with the most experience in the profession did not hold as strong beliefs about constructivist approach as the ones had by the EFLTs with less teaching experience. These results indicate that there is a negative correlation between the increase in the year of teaching experience and the increase in the strength of beliefs about constructivist approach. The EFLTs with less experience in the profession could be more skilled in implementing communicative approach in the classroom as a consequence of the continuing effect of the pre-service teacher education they received, and the ones having spent approximately 20 years in the profession might be in need of training in how to apply it effectively. The literature also entails studies suggesting the provision of training for teachers to lead to shifts in their beliefs (Rosenfeld \& Rosenfeld, 2008; Young \& Sachdev, 2011). It might also result from the level of EFLT motivation in implementing constructivist approach as more experienced EFLTs may be suffering from professional burnout and deem traditional teaching methods as easier to be implemented.

EFLTs' beliefs about effective EFL teaching methods and techniques demonstrated that they agreed with the beliefs as to communicative approach and teaching practices more than the ones concerning grammar translation method. However, more than half of the participants believed that the most significant part of EFL teaching is teaching grammar and almost half of the participants agreed with the item denoting that every mistake made by students should be corrected. In line with these findings, the Chinese EFLTs in Gareca and Gui's (2019) study favoured the use of grammar translation method. Nevertheless, the EFLTs overwhelmingly believed that so long as the message is understood, grammar mistakes could be ignored, showing the value attached to improving students' skills of communicating in English. Moreover, the EFLTs believe, similar to the findings reported in Ghavamnia's (2020) research, knowledge of different cultures can facilitate English language learning. In addition, the EFLTs firmly believe that using interactive activities and pair and group work could promote English language learning, which could be posited to be encouraging in that providing they implement interactive activities in which they promote interaction in English, students could be more motivated to learn English owing to the sense of achievement they gain through speaking English. The percentage values for EFL teaching methods and techniques should not be overlooked and need to be construed to be the indicators of how English language teaching is conducted, because as it is 
prevalently concluded in the existing studies (e.g., Gkonou et al., 2018; Pettit, 2011; Portolés \& Martí, 2020; Rijt et al., 2020; Swierzbin \& Reimer, 2019), teacher beliefs to a large degree mirror what they do in the classroom.

The exploration into the significant changes in EFLTs' beliefs about effective EFL teaching methods and teaching practices according to the level of education they teach and year of their teaching experience revealed that no statistically significant difference was observed in their beliefs about grammar translation method and communicative approach; nonetheless, there was a statistically significant difference in EFLTs' beliefs of teaching practices in accordance with the length of their professional experience. The participants with less teaching experiences believed more strongly that interactive activities could stimulate English language learning, which could result from the continuing effect of pre-service teacher education emphasizing the vitality of promoting the use of interactive activities to maximize interaction in English among students.

\section{Conclusion}

Success in language learning is attributed to successful language teaching. Despite the possibility that teachers' beliefs about effective language teaching may not mediate their classroom practices, the way they teach is shaped by their beliefs. For this reason, uncovering EFLTs' beliefs about effective teaching and learning and effective EFL teaching methods can provide invaluable insights into how they teach English, and in what areas they are in need of professional support. The result reported in this study can be thought-provoking for practicing EFLTs in that the beliefs stated by the research participants could prompt them to ponder upon the impact of their beliefs about effective EFL teaching and student learning on their teaching. Besides, teacher educators can plan their education programs for practicing EFLTs in view of their beliefs in regard to effective EFL teaching methods and techniques, and attempt to unpack pre-service EFLTs' beliefs about effective teaching and learning inasmuch as they will be influencing their future instructional practices.

\subsection{Limitations and Future Implications}

The major limitation of this study is not having the chance to observe at least 5-10 participants' classroom practices to gain an idea about whether or not there is conformity between their stated beliefs and the way they taught English. Therefore, further research should involve classroom observation as well as the questionnaire data as data collection tools. The literature encompasses more studies on pre-service EFLTs' beliefs about effective teaching and student learning than the ones belonging to in-service EFLTs. Hence, more research could be conducted in different contexts to unravel practicing EFLTs' beliefs about teaching and learning, and to explore the probable differences in pre- and in-service EFLTs' beliefs regarding effective EFL teaching and student learning, which could be fulfilled by studies to be carried out with the participation of both sides.

\section{References}

Anderson, J. (2020). 'Buying in' to communicative language teaching: The impact of 'initial' certification courses on the classroom practices of experienced teachers of English. Innovation in Language Teaching and Learning, 14(1), 1-14. https://doi.org/10.1080/17501229.2018.1471082

Baggett, H. C. (2018). "We're here to learn to speak French": An exploration of world language teachers' beliefs about students and teaching. Educational Studies, 54(6), 641-667. https://doi.org/10.1080/00131946.2018.1478836

Bai, B., \& Yuan, R. (2019). EFL teachers' beliefs and practices about pronunciation teaching. ELT Journal, 73(2), 134-143. https://doi:10.1093/elt/ccy040

Bernstein, K. A., Kılınç, S., Deeg, M. T., Marley, S. C., Farrand, K. M., \& Kelly, M. F. (2018). Language ideologies of Arizona preschool teachers implementing dual language teaching for the first time: promultilingual beliefs, practical concerns. International Journal of Bilingual Education and Bilingualism, 24(4), 457-480. https:// doi.org/10.1080/13670050.2018.1476456 
Borg, S. (1998). Talking about grammar in the foreign language classroom. Language Awareness, 7(4), 159-175. https://doi.org/10.1080/09658419808667107

Borg, M. (2001). Teachers' beliefs. ELT Journal, 55(2), 186-188.

Borg, S. (2003). Teacher cognition in language teaching: A review of research on what language teachers think, know, believe, and do. Language Teaching, 36, 81-109. https://doi.org/10.1017/S0261444803001903

Borg, S. (2011). The impact of in-service teacher education on language teachers' beliefs. System, 39(3), 370380. https://doi:10.1016/j.system.2011.07.009

Chaaban, Y. (2017). Examining changes in beliefs and practices: English language teachers' participation in the school-based Support Program. Professional Development in Education, 43(4), 592-611. https://doi.org/10.1080/19415257.2016.1233508

Cheung, A., \& Leung, M. H. (2020). Exploring an ESL teachers' beliefs and practices of teaching literary texts: A case study in Hong Kong. Language Teaching Research, 1-26. doi.org/10.1177/1362168820933447. https://doi.org/10.1177/1362168820933447

Creswell, J. W. (2012). Educational research: Planning, conducting and evaluating quantitative and qualitative research. Pearson.

Crusan, D., Plakans, L., \& Gebril, A. (2016). Writing assessment literacy: Surveying second language teachers' knowledge, beliefs, and practices. Assessing Writing, 28, 43-56. http://dx.doi.org/10.1016/j.asw.2016.03.001

Dale, L., Oostdam, R., \& Verspoor, M. (2018). Towards a professional development tool for teachers of English in bilingual streams: The dynamics of beliefs and practices. International Journal of Bilingual Education and Bilingualism, 1-18. https:/ / doi.org/10.1080/13670050.2018.1556244

Deng, C., \& Carless, D. R. (2010). Examination preparation or effective teaching: Conflicting priorities in the implementation of a pedagogic innovation. Language Assessment Quarterly, 7, 285-302. https://doi.org/10.1080/15434303.2010.510899

Devine, D., Fahie, D., \& McGillicuddy, D. (2013). What is 'good' teaching? Teacher beliefs and practices about their teaching. Irish Educational Studies, 32(1), 83-108. https:// doi.org/10.1080/03323315.2013.773228

Farrell, T. S. C., \& Bennis, K. (2013). Reflecting on ESL teacher beliefs and classroom practices: A case study. RELC Journal, 44(2), 163-176. https://doi.org/10.1177/0033688213488463

Farrell, T. S. C., \& Ives, J. (2015). Exploring teacher beliefs and classroom practices through reflective practice: A case study. Language Teaching Research, 19(5), 594-610. https://doi.org/10.1177/1362168814541722

Feryok, A. (2008). An Armenian English language teacher's practical theory of communicative language teaching. System, 36, 227-240. https:// doi.org/10.1016/j.system.2007.09.004

Fives, H., \& Buehl, M. M. (2012). Spring cleaning for the "messy" construct of teachers' beliefs: What are they? Which have been examined? What can they tell us? In K. R. Harris, S. Graham, T. Urdan, S. Graham, J. M. Royer, \& M. Zeidner (Eds.), APA educational psychology handbook, Vol. 2. Individual differences and cultural and contextual factors (pp. 471-499). American Psychological Association.

Gareca B. C., \& Gui, M. (2019). Chinese and American EFL teachers' beliefs about curricular and pedagogical practices: Cross-cultural similarities and differences. Language and Intercultural Communication, 19(2), 137151. https:// doi.org/10.1080/14708477.2018.1456546

Ghavamnia, M. (2020). Iranian EFL teachers' beliefs and perspectives on incorporating culture in EFL classes. Intercultural Education, 31(3), 314-329. https:// doi.org/10.1080/14675986.2020.1733862

Gkonou, C., Mercer, S., \& Daubney, M. (2018). Teacher perspectives on language learning psychology. The Language Learning Journal, 46(4), 501-513. https:// doi.org/10.1080/09571736.2016.1172330

Graham, S., Santos, D., \& Brophy, E. F. (2014). Teacher beliefs about listening in a foreign language. Teaching and Teacher Education, 40, 44-60. http://dx.doi.org/10.1016/j.tate.2014.01.007

$\mathrm{Gu}, \mathrm{Q}$. (2010). Variations in beliefs and practices: teaching English in cross-cultural contexts. Language and Intercultural Communication, 10(1), 32-53. https:// doi.org/10.1080/13670050.2017.1332000

Harrison, J., \& Lakin, J. (2018). Mainstream teachers' implicit beliefs about English language learners: An implicit association test study of teacher beliefs. Journal of Language, Identity \& Education, 17(2), 85-102. https://doi.org/10.1080/15348458.2017.1397520

Hawanti, S. (2014). Implementing Indonesia's English language teaching policy in primary schools: The role of teachers' knowledge and beliefs. International Journal of Pedagogies and Learning, 9(2), 162-170. https://doi.org/10.1080/18334105.2014.11082029 
Hayes, D. (2009). Learning language, learning teaching: Episodes from the life of a teacher of English in Thailand. RELC Journal, 40(1), 83-101. https:// doi.org/10.1177/0033688208101446

Kagan, D. M. (1992). Implications of research on teacher belief. Educational Psychologist, 27, 65 - 90. https://doi.org/10.1207/s15326985ep2701_6

Karabenick, S. A., \& Noda, P. A. C. (2004). Professional development implications of teachers' beliefs and attitudes toward English language learners. Bilingual Research Journal, 28(1), 55-75. https://doi.org/10.1080/15235882.2004.10162612

Karimi, M. N., Abdullahi, K., \& Haghighi, K. (2016). English as a foreign language teachers' self efficacy as a determinant of correspondence between their professed orientations toward reading and their reading instructional practices. Innovation in Language Learning and Teaching, 10(3), 155-170. https://doi.org/10.1080/17501229.2014.920847

Kissau, S., Rodgers, M., \& Haudeck, H. (2014). Foreign language teaching: An international comparison of teacher beliefs. Research in Comparative and International Education, 9(1), 227-242.

Knudsen, H. B. S., Donau, P. S., L. Mifsud, C., Papadopoulos, T. C., \& Dockrell, J. E. (2021). Multilingual classrooms - danish teachers' practices, beliefs and attitudes. Scandinavian Journal of Educational Research, 65(5), 767-782. https://doi.org/10.1080/00313831.2020.1754903

Lee, R. N., \& Bathmaker, A. M. (2007). The use of English textbooks for teaching English to 'vocational' students in Singapore secondary schools: A survey of teachers' beliefs. RELC Journal, 38(3), 350-374. https://doi.org/10.1080/09588221.2011.630672

Li, L., \& Walsh, S. (2011). 'Seeing is believing': Looking at EFL teachers' beliefs through classroom interaction. Classroom Discourse, 2(1), 39-57. https://doi.org/10.1080/19463014.2011.562657

Li, L. (2013). The complexity of language teachers' beliefs and practice: One EFL teacher's theories. The Language Learning Journal, 41(2), 175-191. https:/ / doi.org/10.1080/09571736.2013.790132

Liviero, S. (2017). Grammar teaching in secondary school foreign language learning in England: teachers' reported beliefs and observed practices. The Language Learning Journal, 45(1), 26-50. https://doi.org/10.1080/09571736.2016.1263677

Ministry of National Education. (2018a). The 2nd-8th Grades English Curriculum. http:/ / mufredat.meb.gov.tr/Dosyalar/201812411191321-

\%C4\%B0NG\%C4\%B0L\%C4\%B0ZCE\%20\%C3\%96\%C4\%9ERET\%C4\%B0M\%20PROGRAMI\%20Klas\%C3 \% B6r\%C3\%BC.pdf.

Ministry of National Education. (2018b). The 9th-12th Grades English Curriculum http:/ / mufredat.meb.gov.tr/Dosyalar/201812020472656-

OGM\%20INGILIZCE\%20PRG\%2020.012018.pdf.

Moodie, I. (2016). The anti-apprenticeship of observation: How negative prior language learning experience influences English language teachers' beliefs and practices. System, 60, 29-41. http://dx.doi.org/10.1016/j.system.2016.05.011

Muñoz, R., \& Ramirez, M. (2015). Teachers' conceptions of motivation and motivating practices in secondlanguage learning: A self-determination theory perspective. Theory and Research in Education, 13(2), 198220. https://doi.org/10.1177/1477878515593885

Murphy, A. F., \& Torff, B. (2019). Teachers' beliefs about rigor of curriculum for English language learners. The Educational Forum, 83(1), 90-101. https://doi.org/10.1080/00131725.2018.1505991

Nguyen, C. D. (2017). Connections between learning and teaching: EFL teachers' reflective practice. Pedagogies: An International Journal, 12(3), 237-255. https:/ / doi.org/10.1080/1554480X.2017.1356725

Nguyen, L., Harvey, S., \& Grant, L. (2016). What teachers say about addressing culture in their EFL teaching practices: The Vietnamese context. Intercultural Education, 27(2), 165-178. https:// doi.org/10.1080/14675986.2016.1144921

Oder, T. (2014). English language teachers' perceptions of professional teaching. Teacher Development, 18(4), 482-494. https://doi.org/10.1080/13664530.2014.953253

Oder, T., \& Eisenschmidt, E. (2018). Teachers' perceptions of school climate as an indicator of their beliefs of effective teaching. Cambridge Journal of Education, 48(1), 3-20. https:// doi.org/10.1080/0305764X.2016.1223837

Pajares, M. (1992). Teachers' beliefs and educational research: Cleaning up a messy construct. Review of Educational Research, 62, 307 - 332. https://doi.org/10.3102/00346543062003307

Pettit, S. K. (2011). Teachers' beliefs about English language learners in the mainstream classroom: A review of the literature. International Multilingual Research Journal, 5(2), 123-147. https://doi.org/10.1080/19313152.2011.594357 
Pham, L. N. K., \& Hamid, M. O. (2013). Beginning EFL teachers' beliefs about quality questions and their questioning practices. Teacher Development, 17(2), 246-264. https:// doi.org/10.1080/13664530.2012.753947

Phipps, S., \& Borg, S. (2009). Exploring tensions between teachers' grammar teaching beliefs and practices. System, 37, 380-390. https://doi:10.1016/j.system.2009.03.002

Portolés, L., \& Martí, O. (2020). Teachers' beliefs about multilingual pedagogies and the role of initial training. International Journal of Multilingualism, 17(2), 248-264. https:// doi.org/10.1080/14790718.2018.1515206

Richards, J. C., \& Lockhart, C. (2007). Reflective teaching in second language classrooms. CUP.

Rijt, J. H. M. V., \& Wijnands, A., \& Coppen, P. A. J. M. (2020). Investigating Dutch teachers' beliefs on working with linguistic metaconcepts to improve students' L1 grammatical understanding. Research Papers in Education, 1-29. https:/ / doi.org/10.1080/02671522.2020.1784258

Rosenfeld, M., \& Rosenfeld, S. (2008). Developing effective teacher beliefs about learners: The role of sensitizing teachers to individual learning differences. Educational Psychology, 28(3), 245-272. https://doi.org/10.1080/01443410701528436

Sanchez, H. S., \& Borg, S. (2014). Insights into L2 teachers' pedagogical content knowledge: A cognitive perspective on their grammar explanations. System, 44, 45-53. http://dx.doi.org/10.1016/j.system.2014.02.005

Sato, M., \& Oyanedel, J. C. (2019). "I think that is a better way to teach but ...": EFL teachers' conflicting beliefs about grammar teaching. System, 84, 110-122. https:// doi.org/10.1016/j.system.2019.06.005

Sun, C., Wei, L., \& Young, R. F. (2020). Measuring teacher cognition: Comparing Chinese EFL teachers' implicit and explicit attitudes toward English language teaching methods. Language Teaching Research. https://doi.org/10.1177/1362168820903010

Swierzbin, B., \& Reimer, J. (2019). The effects of a functional linguistics-based course on teachers' beliefs about grammar. Language Awareness, 28(1), 31-48. https:/ / doi.org/10.1080/09658416.2019.1598423

Tadesse, L. (2020). Problems affecting the practice of student-centered approach in teaching social studies. Journal of Pedagogical Sociology and Psychology, 2(2), 69-79. https://doi.org/10.33902/JPSP.202026294

Tam, A. C. F. (2012). Teachers' misconceptions and questionable practices when using Putonghua as the medium-of-instruction: A case study of Hong Kong. Teachers and Teaching: Theory and Practice, 18(6), 655673. https:// doi.org/10.1080/13540602.2012.746500

Vries, S., Grift, W. J. C. M., \& Jansen, E. P. W. A. (2014). How teachers' beliefs about learning and teaching relate to their continuing professional development. Teachers and Teaching: Theory and Practice, 20(3), 338357. https://doi.org/10.1080/13540602.2013.848521

Watson, A. (2015). The problem of grammar teaching: A case study of the relationship between a teacher's beliefs and pedagogical practice. Language and Education, 29(4), 332-346. https:// doi.org/10.1080/09500782.2015.1016955

Young, T. J., \& Sachdev, I. (2011). Intercultural communicative competence: Exploring English language teachers' beliefs and practices. Language Awareness, 20(2), 81-98. https://doi.org/10.1080/09658416.2010.540328

Zheng, H. (2013). The dynamic interactive relationship between Chinese secondary school EFL teachers' beliefs and practice. The Language Learning Journal, 41(2), 192-204. https://doi.org/10.1080/09571736.2013.790133 